\title{
SHUTDOWN: TWENTY-TWO INDUSTRIAL PLANT CLOSINGS IN THE U.S., 1977-1982
}

\author{
Nancy Torrance Matthews*
}

\section{Introduction}

Since the mid 1970s, hundreds, perhaps thousands, of manufacturing plants in the United States have been partially or totally shut down by their owners. The causes of these shutdowns include shifts in consumer tastes or needs and the inability of companies to keep abreast of those shifts; declines in consumer buying power and the suppliers' resultant inventory surpluses; competition from foreign imports; labor's demands for higher pay and greater benefits; rising costs of supplies and services necessary for production; and the attractiveness of production yielding larger profits and lower costs in other states or foreign nations. In these situations, companies either cease operations, consolidate operations, or move to new locations.

Plant shutdowns affect not just the company and its owners; shutdowns also have dramatic impacts on the workers and their families, on the local government, and on the local unions. As a result of the plant closings, individuals lose their jobs and their families' source of income. Researchers have discovered that certain physical and psychological problems often accompany plant closings-increased incidence of suicide, heart attack, high blood pressure, stroke, alcoholism, as well as child abuse, marital problems, divorce, and crime and violence. The personal trauma of a closing is extended to the community in a ripple effect. When plants close or move, communities lose a portion of their tax base at the same time that their welfare expenditures are increased. The plight of these cities and towns is echoed in newspaper headlines such as "ARCO Pullout Ravages Small Montana Town" and "Once Vibrant Michigan Town is Paralyzed by Debt, Desertion and Pervasive Poverty." (National Catholic Register, January 16, 1981. New York Times, March 21, 1981.) Unions also suffer in the wake of the shutdowns; membership rolls dwindle as union members become unemployed or find other types of jobs. It is a common cry among affected workers, families, communities, and unions that the companies, in particular the larger, multinational corporations, give little or no notice of their intentions to close a plant and provide few considerations such as severance pay, extended benefits, or community compensation to help relieve the trauma caused by the shutdown.

In the wake of mass plant shutdowns in the 1970s and the passions and hardships generated by those closings, a flurry of plant closing legislation has been proposed at the federal and state levels. Common components of the various legislative proposals include requirements for a minimum number of employees, prior notification of the closing, severance pay and extension of benefits, restitution to the affected community, economic impact statements, and government assistance to financially troubled firms in danger of folding. (McKenzie, pp. 8-11.) Advocates of restrictions on plant closings seek through such legislation to restrain the phenomenon of runaway plants or capital flight and to interject social responsibility into the entrepreneurial decision-making process regarding investment and disinvestment in the private sector.

The primary focus of the efforts for plant closing restrictions since 1974 has been in Washington. These determined efforts in Congress, however, have been thwarted by opponents of such legislation, especially in view of the political and economic conservatism engaging Washington since 1980. Thus, proponents have shifted their campaign to the state level. Between 1980 and 1982, proposals for restrictions on industrial shutdowns were introduced into the legislatures of twenty-one individual states, in particular northern industrial states. Despite the concerted efforts of the legislation's advocates, only *Principal Planner, Tennessee Department of Economic and Community Development. 
two states-Wisconsin and Maine-passed plant closing laws, and these acts were somewhat limited in scope. In both instances, the law required as a minimum a plant size of at least 100 employees and a pre-notification period of at least sixty days. Only the Maine law required severance pay (McKenzie, pp. 5-6).

Although only a few specific pieces of plant closing legislation exist on the books, the rather vocal and persistent nature of the movement appears to be having a significant impact on industrial management's dealing with labor and on the handling of plant shutdowns since the mid 1970s. Some union contracts, for example the United Rubber Workers' (URW) contract with several major rubber producers, included as of 1982 requirements for pre-notification and severance pay. In many instances, companies have given upwards of a year's notice to their employees of the company's intention to close a particular plant. Quite a few examples of medical, pension, and other benefits being extended past the date of termination and of efforts by the companies to assist laid-off employees in locating other jobs have been documented. And, in a few situations, companies have offered the communities compensation (in the form of money or land) for the closings. That these issues have been addressed without the force of state and federal laws provides a powerful indication of industry's desire to circumvent the passage of such laws.

\section{Purpose of Study}

The purpose of this study is to examine a small sample of plant shutdowns which occurred during the period between 1977 and 1982 in order to determine whether or not the details of the shutdowns actually bear a resemblance to the provisions in proposed plant closing legislation. Specifically, the details of interest to this study are:

1. The number of employees affected by the shutdown;

2. The dates of the announcement and the actual closing;

3. The amount of notification given to employees and if that was a requirement of a union contract;

4. The granting of severance pay and if it was a union contract requirement;

5. The extension of medical and other benefits past the termination or closing date;

6. The provision of opportunities for employees to transfer to other jobs within the company;

7. Attempts by the company to assist the laid-off workers in locating jobs with other companies; and

8. Efforts by the company to compensate the community for the loss of the plant.

Following a brief discussion of the methodology of the paper, twenty-two individual case studies of plant closings are presented. The discussion of each closing centers around the eight particular types of information enumerated above. The study concludes with an overall evaluation of the sample of shutdowns.

\section{Methodology}

In a preliminary survey of magazine, journal, and newspaper articles published between 1977 and 1982, seventy-seven individual plant shutdowns occurring in the United States during that five year period were identified. The articles surveyed had been collected and assembled by the Data Center of Oakland, California, into a four volume set and the monthly Plant Shutdown Monitor. The four volume collection, entitled Understanding and Combatting Plant Closures, examined several aspects of the plant shutdown phenomenon: why plants close; where do they move; which plants close; the impacts of closure; community, worker, and union responses to closure; and means of counteracting plant closings. The monthly Plant Shutdown Monitor listed recent shutdowns, layoffs, and wage cutbacks in addition to presenting current articles on the subject. The Data Center's clipping collection, covering approximately sixty publications, represented virtually the only source of articles assembled on the subject of plant shutdowns. Without this service, the survey for this paper would have necessitated the tedious task of sorting through the individual publications to locate pertinent articles.

The shutdowns identified in the survey included both partial and total closings. For the purposes of this study, a partial closing was defined as a closing in which only a portion of the total workforce was laid-off; one or more sections of the plant was shutdown, but the plant remained open. A total closing involved a complete cessation of operations, affecting the entire workforce. The closings in this study did not include temporary layoffs for short periods of time, such as two weeks or a month. The study did, however, include those closings classified as indefinite layoffs. 
The articles referring to the specific closings were scrutinized for information relating to closing dates, number of affected employees, notification time, severance pay granted, extension of benefits, transfer offers and other company efforts to help laid off workers find new jobs, and community compensation. Once the preliminary survey was completed, with all available information gathered from the articles on the specific details of the closings, it was evident that in the majority of cases, a significant amount of information on the closings was missing. In most instances, the only information available for a particular shutdown was the date of the closing, location of the plant, or the number of employees involved. Only seven individual closings had most, if not all, of the desired information.

At this point, it was clear that in order to continue the project, it would be necessary to pursue additional sources of information on the plant shutdowns. The most obvious source was the parent companies responsible for the closings. However, fifty-eight different companies were responsible for the seventy-seven cases of plant shutdown. To make the project more tractable, the number of closings to be examined, and thus the number of companies to be surveyed, was reduced. A.more manageable sample size of between twenty and twenty-five cases was decided upon. The range represented the optimal sample size which could be surveyed in the narrow time frame for this project (June-August, 1982).

With the sample size range determined, the selection process for the actual cases to be examined was then established. First, all closings for which the preliminary information for the articles contained at least the date (month and year) of the closing, the location of the plant, and an approximate number of employees affected were chosen for inclusion in the study. The field was narrowed further by the selection of those cases in which the desired information on any or all of the other categories of desired information (severance pay, notification time, extension of benefits, transfers or career counseling, and community compensation) was available. Finally, when a company (such as General Motors, Chrysler, Atlantic Richfield, and Firestone) had multiple closings, the number of that company's closings to be examined was narrowed to only two, with the choice of the particular two cases being determined by the amount of information available on the closing. At the conclusion of the process, twenty-two plant closings involving seventeen companies were chosen for further study.

After the selection of the twenty-two plant shutdowns, a letter was sent to the chairman of the parent company of each plant, requesting their cooperation with this project. The company officials were asked to verify the information already collected on the shutdown and to assist further by furnishing the missing information.

In the following case studies, the twenty-two shutdowns are examined. The case studies are presented in chronological order by the date of the closing announcement, beginning with the earliest announced shutdown. Two categories of closings are distinguished: 1 . those in which the parent company responded to the request for assistance in the study of providing information of the closing; and 2. those for which the information is incomplete due to a lack of response by the parent company.

\section{Case Studies}

The information on these first eleven cases has been assembled with the assistance of the parent companies.

\section{Campbell Steel Works-Lykes, Corporation, Youngstown, Ohio}

The Campbell Steel Works was shut down by the Lykes Corporation on September 23, 1977, with only four days' notice given to the plant's 3,600 workers. The United Steel Workers of America (USWA) contract in effect at the plant contained no provisions for a time requirement concerning notification of a shutdown. The contract did provide for severance pay based on the number of years of service (e.g., those persons with ten years or more of service received eight weeks of pay). Hospital and medical insurance benefits were extended for up to one year, depending upon length of service. Workers also received Supplemental Unemployment Benefits (SUB) and Trade Readjustment Allowance (TRA) eligibility, a further condition of the contract. ${ }^{1}$ In all, Lykes paid $\$ 83$ million in benefits and pensions. 
Once the entire operations of the plant ceased and certain departments were reorganized, those employees with the greatest seniority were rehired to staff a small number of departments whose operations were revived. In addition, a few inter-plant job opportunities were available at Lykes plants in Indiana. The company organized career counseling activities for supervisory, managerial, and executive employees. Hourly workers received no such counseling on a formal basis, although a few skilled tradesmen were placed by Lykes with other companies.

Lykes provided no compensation to the community of Youngstown for the loss of the plant although it did make additional contributions to the United Way Fund in 1978 to compensate for the loss of funds from payroll deductions. (Mother Jones, April, 1978. Wall Street Journal, April 6, 1978, December 22, 1979. Los Angeles Times, July 9, 1979. Dollars and Sense, September, 1980. Wurslich, July 29, 1982.)

\section{General Motors Parts Depot-General Motors Corporation, Oakland, California}

On August 15, 1978, General Motors announced its decision to close the Oakland parts depot by December 1980. The closing was part of the company's effort to consolidate operations at the new depot in Sparks, Nevada. The 388 employees at the Oakland depot received fifteen months' notice of the shutdown, although the union contract required no prior notification. One company official stated that it was corporate policy to give the employees at least six months' notice when possible for a shutdown. (Postma, July 27, 1982.) All of the 388 employees were offered jobs at the Nevada depot; 209 accepted the new positions. Although they received no severance pay, the employees who chose not to relocate received SUB and unemployment compensation together totalling up to one year's income as provided for in the union contract. The United Auto Workers (UAW) contract also called for the extension of medical and other benefits for one year following termination. General Motors did not offer the City of Oakland any form of compensation for the loss of the facility and the jobs. The site has since been sold to a cotton brokerage firm for use as a warehouse. (Oakland Tribune, July 27, 1978. People's World, August 23, 1980. Postma, July 27, 1982.)

\section{Hamtramck Assembly Plant-Chrysler Corporation, Hamtramck, Michigan}

On May 29, 1979, the Chrysler Corporation annonced its intention to cease all operations at the Hamtramck assembly plant by the end of the 1980 model year, in July 1980 . The actual closing occurred prematurely, on January 4, 1980, with one hour's notice given to the 4,500 workers. The plant was thus closed seven months after the original announcement and six months prior to its scheduled closing date. The corporation's announcement of its intention to close the Hamtramck plant included an assurance that Chrysler would make "every effort ... to place affected Hamtramck employees in other Detroit area plants." (Metevier, July 21, 1982.) Approximately 1,800 employees were offered jobs at Chrysler's Jefferson Avenue plant which was scheduled for expansion in the summer of 1980.

Chrysler offered no form of compensation to the community. The plant site was ultimately disposed of through its sale to the City of Detroit for the sum of $\$ 1.00$. The city has since demolished the building, and the site has been slated to be part of a new General Motors assembly plant. (Chrysler Corporation, May 29, 1979. Labor Today, November, 1979. People's World, April 4, 1980. Guardian, April 16, 1980. San Francisco Chronicle, June 8, 1980. Metevier, July 21, 1982.)

\section{Uniroyal Tire Plant-Uniroyal, Inc., Chicopee Falls, Massachusetts}

The local union and employees at the Chicopee Falls plant were notified on January 22, 1980, of Uniroyal's decision to cease operations at the plant as of July 22, 1980. The URW contract with Uniroyal specified that six months' notice be given for such a closing. ${ }^{2}$ Affected by the shutdown were 1,600 hourly and salaried employees. The union contract also specified that the company 1 . give pensions to those workers eligible for retirement (with twenty-five or more years of service or of age fifty-five with at least five years of service), and 2. provide separation or termination pay to all employees based upon their length of service (one to two weeks for each year of service). Employees were further eligible to receive SUB and TRA payments, together totalling 95\% of take-home pay for one year. Full medical benefits for life were given to all employees receiving a retirement allowance; all other employees were granted 
two years of full medical coverage from their last day worked. The URW contract also specified that all employees were eligible for preferential hiring at any other URW Uniroyal plant in the United States. Other than this, Uniroyal made no attempt to assist laid off workers in finding other jobs, and it offered the community no compensation for the loss of the plant. (In These Times, February 13, 1980, April 9, 1980. Business Week, June 23, 1980. Santos, July 21, 1982.)

\section{Lynch Road Assembly Plant-Chrysler Corporation, Detroit, Michigan}

In June 1980, Chrysler announced its intention to close the Lynch Road assembly plant by the end of the 1981 model year, in July 1981. This announcement provided the employees with one year's notice. However, on March 5, 1981, the company released a statement to the effect that operations at the plant would be discontinued on April 3,1981, with less than one month's notice, three months earlier than what had been originally announced. In addition to the 2,500 employees already on indefinite layoff, 2,200 hourly and salaried workers were affected by the closing. Two hundred senior employees at the plant were offered available positions at other local Chrysler plants. The remaining employees were eligible for SUB payments from the company in relation to their years of service (twenty or more years received full benefits) and federal TRA benefits for one year.

In 1982, the City of Detroit negotiated with Chrysler for the purchase of the plant buildings for the sum of $\$ 1.00$ with the "probable objective of demolition and inclusion in an industrial park package for future development." (Wall Street Journal, January 16, 1981, April 3, 1981. Chrysler Corporation, March 5, 1981. Metevier, July 21, 1982.)

\section{Anaconda Copper Smelter-Atlantic Richfield Corporation, Anaconda, Montana}

On October 31, 1980, the Atlantic Richfield Corporation (ARCO) shut down its copper smelter in Anaconda, Montana. Although the union contract required a notification period of seven days for a shutdown, the fact that the 1,220 employees has been on strike since July gave the company cause to nullify that section of the contract. The USWA contract provisions which were fulfilled included severance pay, SUB payments, and the extension of medical, dental, and life insurance benefits. According to a company spokesman, the actual severance pay granted exceeded that called for in the terms of the collective bargaining agreement and was paid for up to one year, based upon years of service. (Miller, August 6, 1982.)

To assist the laid off workers in finding new jobs, ARCO froze all hiring at its other plants while profiles were assembled on the laid off workers at Anaconda. The profiles were distributed to other ARCO plants and matched with available jobs. Those workers who were relocated to other ARCO facilities were paid a sum of money by the company to assist with the burdens of moving. Profiles on workers not re-hired by ARCO were forwarded to nearby companies, and if those workers were called for an interview, ARCO paid the interview expenses. ARCO also announced plans for a land reclamation project on the site and several other medium-term projects which would employ some of the laid off workers.

To assist the communities of Anaconda and Great Falls, both of which were essentially company towns, in dealing with the dramatic economic loss, ARCO gave them $\$ 5$ million in a readjustment fund and donated fifty-five acres of land for the construction of an industrial park. (National Catholic Register, January 16, 1981. Los Angeles Times, February 22, 1981. Washington Post, February 22, 1981. Congressional Record, March 2, 1981. Miller, August 6, 1982.)

\section{Colgate Palmolive Manufacturing Plant-Colgate Palmolive Company, Berkeley, California}

Colgate Palmolive officials met with union representatives and salaried employees at the Berkeley plant in November 1980, to advise them that the company was considering the closure of the plant in an effort to improve overall productivity within the corporation. Although the final decision was not to be made for at least six months and there was no provision in the existing union contract that required prior notice of a shutdown, the company decided to give the employees as much notice as possible. This notice would also allow the company to begin discussions with the union on a settlement package. In April 1981, Colgate and the union agreed on a settlement package to become effective in the event the plant was closed.

The final decision to implement the shutdown came in June 1981, seven months after the initial announcement. After a phase-down period, production at the plant would cease in November 1981. Thus 
the plant's 434 employees received between seven months and one year's notice of the company's intention to shut down the Berkeley plant.

The negotiated settlement between the company and the union gave the employees severance pay equal to one week's pay for each year of service, unused vacation and accumulated sick pay, and a lump sum of between $\$ 400$ and $\$ 1,075$, depending upon length of service. Medical and prescription drug plans were also extended for nine months following termination, and the dental plan benefits were continued for six months. The settlement also included a special provision in the retirement plan for employees under age fifty whose age and years of service equaled seventy years. A comparable benefit package was announced for salaried employees.

Colgate offered transfers to approximately forty professionals, supervisory, and managerial employees. In an effort to assist the remaining employees in job placement, the company contracted with an outplacement consultant to provide several three-day seminars on company time. Colgate offered no compensation to the City of Berkeley for the loss of the plant. (People's World, April 4, 1981. Dietrich, July 22, 1982.)

\section{American Chicle Factory-Warner Lambert Company, Long Island City, New York}

Warner Lambert informed the American Chicle plant employees on April 15, 1981, of its intention to close the Long Island City plant. The final closing took place on February 28, 1982, with the 445 employees having received up to ten months' notice. Since the plant was not unionized, prior notice and severance pay were not required by a union contract. Yet, severance pay averaging $\$ 900$ was granted and health benefits were extended.

Warner Lambert offered to relocate some employees to other company facilities, and the company initiated a Job-Posting program in which open positions within the corporation were posted and employees at American Chicle were permitted to bid for them. Furthermore, Warner Lambert retained the services of two professional outplacement firms who offered assistance through career counseling and resume preparation. Finally, the company established a job center in the plant's personnel office with secretaries available to type resumes for job seekers.

Warner Lambert offered no compensation to Long Island City. The factory was sold to another firm which took possession of the building on March 1, 1982, the day following the shutdown. (New York Times, April 25, 1981. Kuhl, July 15, 1982.)

\section{General Motors Assembly Plant-General Motors Corporation, Fremont, California}

With only two weeks' notice, on March 4, 1982, General Motors announced the indefinite layoff of the 2,500 employees at its Fremont plant. The company attributed the cause of the shutdown to a slump in the California automotive market due to competition from foreign imports. The union contract contained no provisions for prior notification for a layoff, and a company spokesman maintained that it was not feasible in this instance to follow the corporate policy of according at least six months' notice. (Postma, July 27, 1982.) Since the closing was classified as an indefinite layoff rather than a permanent shutdown, no severance pay was granted. However, the workers were eligible to draw SUB payments equivalent to $90 \%$ of take-home pay for up to one year, varying with seniority, by the terms of the contract. Medical benefits were extended as well.

Several hundred skilled workers were offered transfers to the Leads assembly plant in Kansas City, Missouri. To aid other workers in finding new jobs, General Motors instituted in-plant programs to teach job interviewing and resume writing skills. Since the plant was not permanently closed, the company made no offer at that time to compensate the community. (Oakland Tribune, March 6, 1982. Postma, July 27, 1982.)

\section{General Tire Plant-General Tire Company, Akron, Ohio}

In March 1982, General Tire announced the closing of its Akron tire production facility scheduled for the end of 1982 . The more than 1,000 employees at the plant were given the six months' notice as provided for in the URW contract with General Tire. Hourly workers received no severance pay. The collective bargaining agreement and the supplemental agreements on pensions, insurance, and SUB payments, however, required the distribution of SUB and pension funds to hourly workers on the basis of age and years of service. Salaried employees were granted separation pay on the basis of years of 
service. Both hourly and salaried employees received two years of hospitalization, major medical, surgical, medical, prescription drug, and life insurance coverage following termination. All retirees were covered for life under the company's comprehensive life insurance program.

Regarding transfers, the union contract did not provide for preferential hiring rights within the company for hourly workers. Although exactly what these efforts were was not specified, a company spokesman stated that efforts had been made to secure employment opportunities for both salaried and hourly personnel. (Pittenger, July 30,1982.) No consideration was offered to the community for the loss of the plant. (Wall Street Journal, March 2, 1982. Pittenger, July 30, 1982.)

Berkeley Copper Pit-Atlantic Richfield Corporation, Butte, Montana.

On April 23, 1982, ARCO gave its employees at the Berkeley copper pit one week's notice of its intention to institute a partial shutdown. Of the 1,070 employees at the plant, 207 were laid off. The union contract required seven days' notice and severance pay. The laid off workers were further entitled to receive up to one year of SUB payments based upon years of service. Medical, dental, and life insurance benefits were also extended as required by the union agreement for an undisclosed time.

The handling of relocation efforts for the affected employees was identical to that at the Anaconda smelter in 1980. Hiring was frozen in the company while profiles on the workers were prepared, distributed, and matched to available positions. Profiles were also sent to other companies to aid the laid off workers in locating other jobs. Since the closing was only partial and because Butte was not considered a company town as was Anaconda, ARCO offered the community no compensation. (New York Times, April 25, 1982. Miller, August 6, 1982.)

The following case studies are incomplete due to the lack of response from the parent companies.

\section{Mohawk Rubber Plant-Mohawk Rubber Company, Akron, Ohio}

On Thanksgiving Day, 1978, the Mohawk Rubber plant in Akron was shut down completely with only nine days' notice having been given to the plant's 318 employees. The laid off employees were entitled to TRA benefits, and those eligible for retirement received pensions. (US News and World Reports, May 21, 1979.)

\section{Ohio and McDonald Works-U.S. Steel Corporation, Youngstown, Ohio}

On November 27, 1979, U.S. Steel announced the closing of fifteen of its domestic plants, closings which terminated more than 13,000 jobs. Two of those plants were the Ohio and McDonald Works in Youngstown, Ohio which are generally referred to as one operation. The closings, occurring between March and June, 1980, affected a total of 3,500 workers in the two plants. These workers were given four to seven months' notice of the termination of their jobs.

The employees sought to block the closings, insisting that U.S. Steel had a binding agreement with the workers to keep the two plants open; a federal judge disagreed with the workers' assertion. When the workers then offered to buy the plants with federal aid, U.S. Steel refused the offer, preferring instead to depreciate the cost of the shutdowns. The company stated that it would not sell to a government subsidized competitor. (Christian Science Monitor, November 29, 1979. Guardian, April 16, 1980. Dollars and Sense, September, 1980. Labor Unity, February, 1981.)

\section{Firestone Tire Plant-Firestone Tire and Rubber Company, Barbertown, Ohio}

On March 19, 1980, Firestone announced the closing of five of its eighteen domestic plants by October 1980 , thus giving employees the six months' notice as required by the URW contract. The 1,105 employees at the Barbertown plant received severance pay, a requirement written into the contract a short time earlier to cover just such an event, and eligibility for TRA benefits. The settlement between the union and the company called for the payment of the sum of $\$ 75$ per week for a total of six months to each unemployed worker. As guaranteed by the contract, workers were also given preferential hiring rights at all URW Firestone plants. (New York Times, March 20, 1980. In These Times, April 9, 1980. Guardian, April 26, 1980. Business Week, June 23, 1980.)

\section{Firestone Tire Plant-Firestone Tire and Rubber Company, Salinas, California}

A second Firestone plant whose closing was announced in March 1980, was the facility in Salinas, California. Although the announced shutdown date was October 1980, the closing occurred by July 30 , 
1980, with only four months' actual notice. Like the workers at the Barbertown plant, the 1,660 Salinas employees received severance pay and TRA eligibility. The company also hired a career development team to counsel the workers, in addition to their preferential hiring rights guaranteed by the union contract. (New York Times, March 20, 1980. San Francisco Examiner, March 21, 1980, December 4, 1980. In These Times, April 9, 1980. Oakland Tribune, April 12, 1980. Guardian, April 26, 1980. Business Week, June 23, 1980.)

\section{Ford Assembly Plant-Ford Motor Company, Mahwah, New Jersey}

Ford announced on April 16, 1980 the shutdown of its Mahwah assembly plant. The plant's 4,500 employees were given two months' notice before the actual closing on June 21, 1980. The employees received compensation from Ford, the UAW, and the State of New Jersey, amounting in all to $95 \%$ of take-home pay for fifty-two weeks. Of the total workforce, 350 affected workers were offered transfers to the assembly plant in Metuchan, New Jersey. The New Jersey Department of Labor and Industry established a job referral and retraining center at the local UAW headquarters. (People's World, April 26, 1980. New York Times, May 27, 1980, June 21, 1980.)

\section{Kaiser Light Steel Products Plant-Kaiser Steel Corporation, Fontana, California}

Kaiser Steel announced on January 15, 1981 its decision to institute a total shutdown of the Fontana plant by March 1, 1981. The 138 employees, including sixteen managerial staff persons, were given one and a half months' notice of the shutdown. Following the closing, each employee received termination benefits of an undisclosed nature. Two plant managers were offered transfers to other positions within the company. (Oakland Tribune, January 16, 1981.)

\section{General Electric Clothes Iron Plant-General Electric Company, Ontario, California}

General Electric made public its decision to shut down its Ontario clothes iron plant in June 1981, giving the 850 workers approximately eight months' notice. After the closing occurred on February 26, 1982, the laid off employees received severance pay. The company refused a worker buyout offer, choosing instead to accept a bid by the Casablanca Fan Company. The fan company was to provide only 200-300 low wage jobs for the Ontario community. (Wall Street Journal, January 27, 1982.)

\section{Guardian Windshield Glass Plant-Guardian Industries, Detroit, Michigan}

Guardian Industries announced on Friday, October 2, 1981, that the Detroit windshield glass factory would be closed permanently effective Monday, October 5, 1981. The plant's 200 employees were thus given less than one working day's notice of their layoff. At first, the company offered only the contractually obligated pension benefits to those workers eligible for retirement. After a legal battle, the UAW won severance pay awards of $\$ 300$ per year of service, as well as lifetime health and life insurance and medical cost benefits for regular and early retirees and fifteen months' free health insurance to all other affected employees. The company was obligated to reimburse all employees for vacation pay through May 1982. The total cost of all benefits exceeded $\$ 2$ million. (Solidarity, February, 1982.)

\section{Ford Assembly Plant-Ford Motor Company, Norfolk, Virginia}

On January 29, 1982, Ford announced the partial closing of its Norfolk assembly plant. The 700 employees on the plant's second shift were given two weeks' notice of the termination of their jobs. According to the terms of the union contract, all laid off workers were entitled to SUB payments, but due to the near depletion of the fund from other Ford plant closings, only those workers with ten or more years of service were actually eligible. (Washington Post, February 7, 1982.)

\section{Kerr McGee Plant-Kerr McGee Chemical Corporation, Trona, California}

On March 21, 1982, Kerr McGee announced the partial closing of its Trona plant. The partial shutdown, affecting 475 employees in a total workforce of 1,600 , was scheduled to begin on March 29 and continue for two months. Severance pay was granted and health insurance coverage extended for six months past the termination date. In order to ease the financial burden of relocation, Kerr McGee offered to buy the homes of those employees who lived in the City of Trona and who had to move to another place to find a new job. (San Francisco Chronicle, March 27, 1982.) 


\section{Sperry New Holland Plant-Sperry Corporation, Fowler, California}

Sperry made public on April 24, 1982 its intention to shut down the Fowler farm equipment manufacturing plant with layoffs scheduled to begin on May 1, 1982 and continuing through the month of August. The 320 employees (200 production and 120 office personnel) had between one week and four months' notice of their termination. Although the plant was not unionized, the employees received severance pay amounting to one week's pay for each year of service (averaging ten to eleven weeks). (San Francisco Chronicle, April 25, 1982.)

\section{Conclusions}

The twenty-two plant shutdowns discussed in the previous section represent only a small percentage of the total number of plant closings occurring in the United States between 1977 and 1980 . Because of the small sample size, danger lies in any attempt to draw broad inferences concerning the industrial shutdown phenomenon in this country. Some danger also exists in relying too heavily upon the accuracy or objectivity of the sources. The issue of plant closings is fraught with emotion, a fact which makes a researcher's job of searching for accurate information all the more difficult. Newspaper and magazine articles are prone to present the sensational or human interest side of the story, while the accounts of company representatives are more likely to try to justify their companies' actions. These types of sources, however, were the most convenient and practical means of securing the information desired for this study. Therefore, it was necessary in the preparation of this study to scrutinize the sources carefully and to present as objectively as possible the facts of the shutdowns.

Despite the drawbacks of the study's format, some interesting observations can be made. The preliminary survey of newspaper and magazine articles brings into focus several issues regarding the subject of plant shutdowns.

1. Of the seventy-seven closings identified, thirty-five of them occurred in regions other than the northern industrial tier from which most of the clamor for plant closing legislation has originated. The western and southern regions, those areas, according to the literature, to which plants from the northern states are moving, also experienced major shutdowns between 1977 and 1982. More than a quarter of the total closings identified were in the state of California alone.

2. The vast majority of shutdowns surveyed involved unionized plants. This fact should not be surprising since unions use publicity of the closings to gain greater leverage for their position when bargaining with companies over the details of a closing.

3. More than $90 \%$ of the plant shutdowns surveyed affected a minimum of 100 workers. The largescale shutdowns generally receive more publicity due to their magnitude and their effect upon workers and communities. However, small businesses and plants, with fewer than 100 workers, have traditionally had a higher rate of failure than do larger businesses.

4. Only one of the plants surveyed was engaged in the textile industry. The remainder were primarily rubber, steel, or automotive; these three industries, which are heavily unionized, have been concentrated historically in the northern and western states. Textiles, traditionally concentrated in southern and northeastern states and generally non-unionized, are noticeably absent from the literature. Yet, the textile industry has been suffering as well from plant closings and layoffs.

Geographically, the twenty-two case studies are distributed in the following fashion:

Region

North

Mid Atlantic

South

West

(California)
\# of Closings

9 
The greatest number of closings in this study have occurred in the western region of the United States, primarily in California. This geographical distribution is not, however, representative of the total number of closings throughout the nation. Rather, it is probably due to a bias in the sources of articles collected and reprinted by the Data Center.

As a direct result of these shutdowns, the positions of approximately 32,400 workers were terminated. This amounted to an average of 1,473 workers per plant shutdown, with the actual number of affected employees at the individual plants ranging from 138 to 4,500 .

The notice time given ranged from one day or less (at Chrysler-Hamtramck, ARCO-Anaconda, and Guardian) to fifteen months (at General Motors-Oakland). The average notification for this study group was 3.7 months, although in several instances, the notification time varied for different workers at the same plant. The median amount of notice time was six to nine months. In only six cases did the union contracts for the plants require prior notification, and in two of those cases, the actual notice given was less than that required by the contract (Anaconda Copper Smelter and Firestone's Salinas plants).

With regard to the issue of severance pay, in all but one (General Motors-Oakland) of the 18 plant closings for which such information was available, the laid off employees received some amount of severance pay. In ten of the first eleven cases discussed (those with input from company representatives), the union contracts contained provisions which requied severance pay. In the other case (American Chicle), the plant was not unionized. Although the information is not complete for the remaining eleven cases, only one plant's union contract did not require severance pay when in fact the company (Guardian) actually granted the pay.

Medical and/or other benefits were extended in every instance in which information on the subject was available. The benefits ranged from eligibility for SUB and TRA payments to the continuation of hospitalization, medical, prescription drug, and/or dental insurance. The amount of time for which major insurance benefits were extended ranged from six months to two years, with the average being about one year.

To varying degrees, transfers were offered to some employees at each of the thirteen plant closings on which such information was available. The extent of the transfer offers varied from the relocation of a few executive or management personnel at Kaiser to the offer to all affected employees for preferential hiring rights at other company plants by ARCO and General Motors. At nine of the thirteen plants, the parent companies took measures to aid their laid off employees in finding other jobs. Several of these companies hired professional outplacement firms and career counseling teams to provide assistance with job interviews and resume preparation on company time. Other efforts included the compilation by ARCO of profiles on workers to be sent out to other companies and the use of in-plant Job Posting programs such as the one at American Chicle.

In only one of the twelve instances for which information was available on community compensation did the company (ARCO) provide compensation to the affected communities (Anaconda and Great Falls, Montana) for the economic loss. This may indicate that while companies may have granted severance pay, extended benefits, offered transfers, and made other efforts to assist workers in locating new jobs, the majority of firms in this study did not consider community compensation to be a realistic obligation or responsibility. The issue of notification, severance pay, extension of benefits, and job security have been dealt with by unions and companies through the collective bargaining process. The issue of community compensation may eventually be settled through the negotiation of agreements between companies and local governments as a preliminary to the location of a plant in a community.

The case studies presented in this paper do seem to indicate that some companies have worked with the unions, or directly with the employees in non-unionized plants, to settle some of the issues involved in a plant shutdown. Perhaps the major incentive for such actions by companies has been the looming proposals for state or federal plant closing restrictions. From the cases examined, the conclusion may be drawn that some of the fundamental issues in the proposed plant closing legislation were addressed without the force of law, and the reason may have been to avoid the necessity of such a law. Severance pay was granted, benefits were extended, and transfers and/or outplacement opportunities were offered to at least some of the employees involved in plant shutdowns.

By no means are the findings of this study purported to be conclusive evidence of absolute trends in the plant shutdown phenomenon. The study does reveal certain directions found in the twenty-two 
shutdowns examined which may or may not be characteristic of the far greater number of closings occurring between 1977 and 1982, and in the years since then. Further research into the topic is certainly needed. One obvious direction for future research is the examination of a larger number of closings in all of the major industries: steel, automotive, rubber, forestry, chemical, electronics, and of course textiles. Furthermore, an investigation of the details of closings in the various sections of the nation might reveal some interesting regional differences in corporate shutdown strategies. And, of course, other sources of information of plant closings, such as union records, should provide additional information of the details of the industrial shutdown phenomenon affecting the United States.

\section{FOOTNOTES}

1Supplemental Unemployment Benefits (SUB) were negotiated in union contracts to help close the gap between wages and regular unemployment payments. The Trade Readjustment Allowance (TRA) is a federally subsidized supplemental unemployment benefit that provides $70 \%$ of annual salary for one year to those workers whose jobs were lost due to competition from imported goods.

2The 1979 URW contract specified that the company must negotiate with the union to save the plant; if the plant cannot be saved then the company must negotiate with the union the details of the closing. - In These Times, April 4, 1980.)

\section{REFERENCES}

Business Week, June 23, 1980.

Christian Science Monitor. November 29, 1979.

Chrysler Corporation. News Releases dated May 29, 1979 and March 5, 1981.

Congressional Record. March 2, 1981.

Dietrich, C.H., Director, Industrial Relations, Colgate Palmolive Company. Letter dated July 22, 1982.

Dollars and Sense. September, 1980.

Guardian. April 16, 1980; April 26, 1980.

In These Times. February 13, 1980; April 4, 1980; April 9, 1980.

Kuhl, Thorn, Public Affairs, Warner Lambert Company. Letter dated July 15, 1982.

Labor Today. November, 1979.

Labor Unity. February, 1981.

Los Angeles Times. July 9, 1979; February 22, 1981.

McKenzie, Richard B. The Right to Close Down: The Political Battle Shifts to the States. Original Paper 35, International Institute for Economic Research, January, 1982.

Metevier, T.E., Director, State and Local Government and Community Relations, Chrysler Corporation. Letter dated July 21, 1982.

Miller, Don, Spokeman, Atlantic Richfield Corporation. Telephone interview on August 6, 1982.

Mother Jones. April, 1978.

National Catholic Register. January 16, 1981.

New York Times. March 20, 1980; May 27, 1980; June 21, 1980; March 21, 1981; April 25, 1981; April $25,1982$.

Oakland Tribune. July 27, 1978; April 12, 1980; January 16, 1981; March 6, 1982.

People's World. April 4, 1980; April 26, 1980; August 23, 1980; April 4, 1981.

Pittenger, T.E., Vice President, Legal, General Tire Company. Letter dated July 30, 1982.

Postma, M., Spokesman, General Motors Corporation. Telephone interview on July 27, 1982.

San Francisco Chronicle. June 8, 1980; March 27, 1982; April 25, 1982.

San Francisco Examiner. March 21, 1980; December 4, 1980.

Santos, William A., Industrial Relations, Uniroyal, Inc. Letter dated July 21, 1982.

Solidarity. February, 1982.

US News and World Report. May 21, 1979.

Wall Street Journal. April 6, 1978; December 22, 1979; January 16, 1981; April 3, 1981; January 27, 1982 ; March $2,1982$.

Washington Post. February 22, 1981; February 7, 1982.

Wurslich, Gary, Senior Manager, Industrial Relations, Jones and Laughlin Corporation. Telephone interview on July $29,1982$. 